\title{
Comparative efficiency of different realization methods of cathodic protection for marine structures
}

\author{
Boris Borisovich Chernov ${ }^{1, *}$, Van Mung $\mathrm{Vu}^{1,2}$, Anas Maskharovich Nugmanov ${ }^{1}$ \\ ${ }^{1}$ Maritime State University named after adm. G.I. Nevelskoy, 690059, Vladivostok, Russia \\ ${ }^{2}$ Vietnam Maritime University, 180000, Haiphong, Vietnam
}

\begin{abstract}
Economic efficiency in using the solar panels as the DC sources for the impressed current cathodic protection of offshore structures was compared with the sacrificial anode cathodic protection. The calculation was based on the example of a sheet pile wall with a surface area of $2000 \mathrm{~m}^{2}$ protected by various methods of cathodic protection: the impressed current cathodic protection powered by a rectifier device, by solar panels with batteries, by solar panels without batteries and sacrificial anode cathodic protection. The results showed that the cost of impressed current cathodic protection powered by solar panels without batteries is the lowest after 10 years of operation. Cathodic protection powered only by solar panels without batteries is the most beneficial in cold climates when battery life is reduced, and for facilities that are remote from centralized power sources, where the power supplying cost to the protected structure is difficult to estimate due to specific situations.
\end{abstract}

\section{Introduction}

The most effective protection method of marine metal structures is electrochemical protection $[1,2]$. These structures are often located far away from stationary sources of electric current and the power transmission to them is very expensive or difficult. Therefore, the question often arises about the advisability of using autonomous DC sources. Solar panels are such a reliable DC source with a service life of more than 25 years. They have one significant drawback - they do not generate electricity at night, and for the continuity of the cathodic protection operation, a cathodic protection system must include batteries that have a significantly shorter service life compared to solar panels and require periodic replacement and maintenance.

Cathodic protection of offshore structures is accompanied by the formation of calcareous deposits on the metal surface [3-6], which have a protective ability $[7,8]$. This protective feature allows the cathodic protection current to be disconnected for a certain period, for example, for repair or replacement of anodes. It was shown that cathodic protection powered only by solar panels without batteries has sufficient protection at current densities over $200 \mathrm{~mA} / \mathrm{m}^{2}[9,10]$. This kind of protection can combine with the other traditional protection methods to have better efficiency.

The purpose of this work is the comparative economic efficiency of the different realization methods of cathodic protection for offshore structures.

\section{Cost calculations of the different realization methods of cathodic protection}

The comparative economic efficiency of cathodic protection of offshore structures is conveniently carried out with the example of a sheet pile wall with a protected surface area of $2000 \mathrm{~m}^{2}$. The initial data for such a calculation are presented in the below table 1 .

To estimate the economic efficiency of cathodic protection of offshore structures, the cost is divided into the installation cost and the operating cost.

Four methods of cathodic protection are considered as follows:

- cathodic protection powered by a rectifier;

- cathodic protection powered by solar panels with batteries;

- cathodic protection powered by solar panels without batteries;

- sacrificial anode cathodic protection.

Table 1. Initial data of sheet pile wall.

\begin{tabular}{|l|c|}
\hline \multicolumn{1}{|c|}{ Parameter } & Value \\
\hline Wall length, $\mathrm{m}$ & 150 \\
\hline Depth of water, $\mathrm{m}$ & 10 \\
\hline $\begin{array}{l}\text { The specific electrical } \\
\text { conductivity of water, S/m }\end{array}$ & 3 \\
\hline $\begin{array}{l}\text { Specific cathodic polarizability of } \\
\text { steel, } \Omega \mathrm{m}^{2}\end{array}$ & 5 \\
\hline $\begin{array}{l}\text { Stationary potential of steel in } \\
\text { water, V (SCE) }\end{array}$ & $-0,35$ \\
\hline
\end{tabular}

\footnotetext{
* Corresponding author: chernov.bor@yandex.ru
} 


\begin{tabular}{|l|c|}
\hline $\begin{array}{l}\text { Minimum protective potential of } \\
\text { steel in water, V (SCE) }\end{array}$ & $-0,55$ \\
\hline Insoluble anode type & $\begin{array}{c}\text { Platinized } \\
\text { titanium Ti (Pt) }\end{array}$ \\
\hline
\end{tabular}

The initial cost for the cathodic protection powered by a rectifier is 200 thousand rubles including the cost of a cathode station with anodes and connecting cables. The calculations were based on the documents [11-13]. The operating cost depends on the cost of electricity $(5$ rubles/kWh).

The calculation for the cathodic protection powered by solar panels with batteries is similar to the calculation for the autonomous power supply of consumers without a centralized power supply. This approach is based on the determination of the energy required to implement the cathodic protection of an object in seawater.

The power consumed by the cathodic protection is calculated by the formula:

$$
N=S i U
$$

Where $S$ - the surface area of the protected offshore structure; $i$ - cathodic protection current density, which is considered equal to $50 \mathrm{~mA} / \mathrm{m}^{2}[11,12] ; U-$ the rated voltage of the direct current source during the operational period, $2.5 \mathrm{~V}[11,12]$.

Hence, the power and the consumed energy per day during the operating period are equal

$$
N_{I}=2000 \times 0,05 \times 2,5=250 \mathrm{~B} \text { T and }
$$

$$
E=N_{l} \times 24=6000 \mathrm{Wh} \text {. }
$$

To ensure the accumulation of such energy, a battery with a capacity of $500 \mathrm{Ah}$ of $12 \mathrm{~V}$ should be used, capable of energy storage up to $6000 \mathrm{kWh}$. To maximize the service life of batteries, do not allow them to discharge more than $25 \%$. With this in mind, batteries with a capacity of four times that are required, namely $2000 \mathrm{Ah}$. Due to the gradual decrease in the capacity of the battery during its operation, the original capacity should be increased by another 1.5 times. Thus, in the practical realization of cathodic protection, some batteries with a total capacity of 3000 Ah should be installed. This assumes the use of 14 rechargeable batteries with a capacity of 220 Ah each one with some energy spare. We will assume that the cost of such batteries will be 218.6 thousand rubles.

To determine the number of solar panels and their capacity, the solar insolation $\beta$ for the area of protection of the marine structure should be taken into account, which we consider on average equal to $4000 \mathrm{Wh} / \mathrm{m}^{2}$ per day for the Vladivostok area. Taking into account also the coefficient $\theta$ of incomplete conversion of energy from a solar panel to a battery $(\theta=1.3 \div 1.5)$, it is possible to estimate the power received from solar panels, which is necessary to ensure cathodic protection

$$
W_{p}=\frac{N_{1} \times t \times \theta \times E_{C T}}{\beta}=\frac{250 \times 24 \times 1,3 \times 1000}{4000}=1950 \mathrm{~W}
$$

where $E_{C T}=1000 \mathrm{~W} / \mathrm{m}^{2}-$ power under standard conditions; $t$ - the operating time per day.
Based on the required power of the solar panels and assuming that 8 solar panels with a capacity of $250 \mathrm{~W}$ each one are used for its realization, their cost will be 63.12 thousand rubles.

Therefore, the cost of batteries is almost 4 times higher than the cost of solar panels, and the total cost of the batteries and solar panels is 281.72 thousand rubles. The total price of all cathodic protection system powered by solar panels with batteries, including the controller, insoluble anodes, and commutation wires, should not exceed 320 thousand rubles.

For cathodic protection powered only by solar panels without batteries, the protective ability against corrosion of offshore structures is achieved through the formation of protective coatings of $\mathrm{CaCO}_{3}$ and $\mathrm{Mg}(\mathrm{OH})_{2}$ during the daytime, which can protect objects from corrosion in the night. To assess the cost of unpainted protecting offshore structures that must be protected at night with calcareous deposits, structures should be protected at a higher current density of 0.25 $\mathrm{A} / \mathrm{m}^{2}$.

If we assume that the rated voltage of the direct current source during the operating period is $8 \mathrm{~V}[11$, $12]$, the initial required power of solar panels is

$N_{2}=2000 \times 0.25 \times 8=4000 \mathrm{~W}$.

Take into account the conditions of solar insolation $\beta$ for the protection position (for Vladivostok $\beta=4000$ $\mathrm{Wh} / \mathrm{m}^{2}$ per day), then the power of solar panels required to provide cathodic protection is equal to $\frac{N_{2} \times t \times E_{C T}}{\beta}=\frac{4000 \times 8 \times 1000}{4000}=8000 \mathrm{~W}$.

So, 27 solar panels with a power of $300 \mathrm{~W}$ should be installed with some energy spare.

If we assume that 27 panels are used at 10.6 thousand rubles each one, the total cost of solar panels is 282.6 thousand rubles, then the total installing cost of all cathodic protection system powered by solar panels without batteries, consisting of the insoluble anodes and connecting wires, should not exceed 310 thousand rubles.

When using sacrificial anode cathodic protection, the cost of anodes can be estimated by the expression:

$$
P_{p r}=S_{p r} \times M_{p r}
$$

where $S_{p r}$ - the cost of a $\mathrm{kg}$ of the anode $\left(S_{p r}=250\right.$ rubles $/ \mathrm{kg}$ for the aluminum anode), $M_{p r}$ - required mass of anode per year.

The calculation according to $[11,12]$ shows that to protect the sheet pile wall, a mass of AP3 anode (aluminum anode) is required annually

$$
M_{p r}=\frac{S \times i \times 8760}{\varepsilon \times \mu}=448.77 \mathrm{~kg} / \text { year }
$$

where $\varepsilon$-actual current output ( $\varepsilon=2440$ for AP3 [11]), $\mathrm{Ah} / \mathrm{kg} ; \mu-$ efficiency factor $(\mu=0.8$ for AP3 [11]); $i=$ $50 \mathrm{~mA} / \mathrm{m}^{2}$.

With such a sample, the total installing cost of anodes each year will be 112.19 thousand rubles. Annually if we assume that they should be replaced every five years, then their cost until the next replacement will be 560.95 thousand rubles. 
The below figure 1 shows the estimated costs (installing and operating) for various realization options for cathodic protection of a sheet pile wall with an area of $2000 \mathrm{~m}^{2}$ in the service life of up to 25 years. The calculation has already considered that the batteries must be replaced every 7-10 years due to their limited service life.

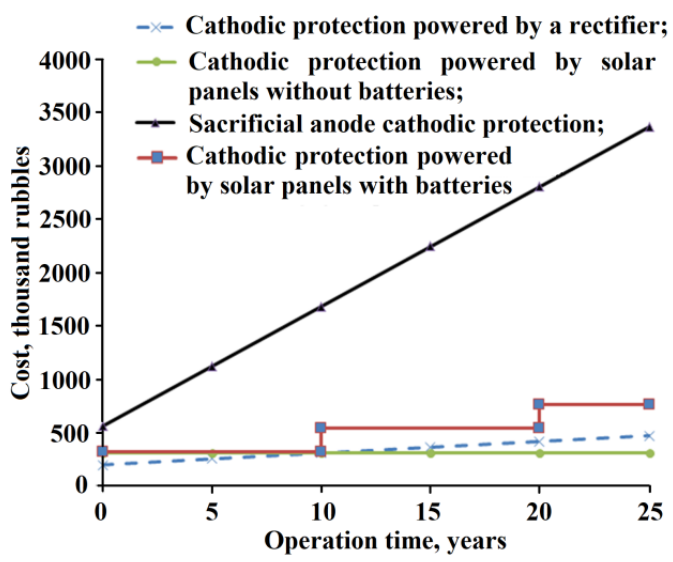

Fig. 1. The protecting cost of the sheet pile wall from corrosion for 25 years with various options for cathodic protection.

It can be seen from the figure that the cost of sacrificial anode cathodic protection, cathodic protection powered by solar panels with batteries, and cathodic protection powered by a rectifier device raise with the operating time and the cost of cathodic protection powered by solar panels without batteries is constant over time. The installation costs of electrochemical protection for all options are close to each other, except the sacrificial anode cathodic protection. These results are consistent with the results of work [13], where the technical and economic characteristics of electrochemical protection for ships were compared. The cost of the sacrificial anode cathodic protection is always higher at any time since it requires replacement of worn anodes. At the same time, the cost of cathodic protection powered by solar panels without batteries justifies itself after 10 years of operation and shows a twofold saving by 25 years of operation compared to other types of cathodic protection. The cost calculation of cathodic protection supplied from a rectifier device did not include the costs of its replacement and maintenance (repair, replacement of parts, etc.) and the supply of power from centralized sources of electricity. Considering such difficultly determined costs, which can only be estimated for each specific case, the most advantageous option in the practice of cathodic protection is the option with the use of solar panels.

\section{Conclusions}

It should be especially noted that the use of fully autonomous cathodic protection from solar panels without batteries is highly beneficial in the cold conditions of the Arctic. In such climatic conditions, cathodic protection powered by solar panels without batteries is the most cost-effective and allows to reliably protecting marine structures located at a distance from centralized power sources and human resources.

\section{References}

1. W.H. Hartt, Corrosion, 68, 12, (2012)

2. M. Grabowski, S.Virtanen, Corrosion, 73, 5, (2017)

3. B.B. Chernov, V.M. Vu, A.M. Nugmanov, L.Yu. Firsova, Marine Intellectual Technologies, 2, 3(37), (2017)

4. B.B. Chernov, V.M. Vu, A.M. Nugmanov, L.Yu. Firsova, Marine Intellectual Technologies, 5, 4 (42), (2018)

5. V.M. Vu, A.M. Nugmanov, B.B. Chernov, Russian J. of Phy. Chem. A, 93, 5, (2019)

6. C. Barchiche, C. Deslouis, O. Gil, S. Joiret, Ph. Refait, B. Tribollet, Electrochimica Acta, 54, (2009)

7. Ph. Refait, M. Jeannin, R. Sabot, H. Antony, S. Pineau, Corrosion Science, 71, (2013)

8. F.G. Liu, S.R. Wu, C.S. Lu, Corrosion Engineering, Science and Technology, 46, 5, (2011)

9. B.B. Chernov, V.M. Vu, A.M. Nugmanov, L.Yu. Firsova, E3S Web of conferences, 121, 02004, (2019)

10. B.B. Chernov, A.M. Nugmanov, Marine Intellectual Technologies, 33, 3(1), (2016)

11. RD 31.35.07-83, Moscow, (1983)

12. DNV-RP-B401, Hevik, Norway: Det Norske Veritas, (2010)

13. Ye.M. Gramuzov, A.V. Rod'kina, O.A. Ivanova, Vestnik Volzhskoy gosudarstvennoy akademii vodnogo transporta, 60, (2019) 